УДК 72.03

ББК $85.11 ; 63.3$ (2Р-4СПБ)

DOI:10.18688/aa155-9-94

Ekaterina Staniukovich-Denisova

\title{
Sankt-Peterburg of Peter I: The History of Household Possession - Site Development, Owners and Builders by Mariia V. Nikolaeva. Moscow: Progress-Traditsiia Publ., 2014
}

The Petrine time in the architecture of St. Petersburg marked the resolute turn to the European building tradition in the new capital of Russia. The transformation process of Russian mediaeval practice let art historians compare the role of the late $17^{\text {th }}-$ early 18 th century in the evolution of the national art school with that of the Renaissance in Western Europe. It concerned not only innovative methods of fortification and engineering, rich palatial architecture, but a wide range of civil buildings and urban planning.

Though the interest in early architecture of the city persisted since Petr N. Petrov published his fundamental book "The history of St. Petersburg from the foundation of the city" (1884) and was developed by Igor' Grabar' in the third volume of the prerevolutionary "History of Russian Art", the aspects of the customer - artist relationship started to be considered only in the Post-Soviet historiography. The difficulty of studying Petersburg household possession stemmed from the lack of original documentary in situthe Police archives were burnt by insurgents during the 1917 February revolution, other materials were moved to Moscow, the new capital, and accumulated at the Russian State Archive of Ancient Acts (RGADA). In the 1950s-1990s Petersburg (Leningrad at that time) researchers did not have enough possibilities to use Moscow depositories systematically, nevertheless important data concerning allotment and building development of some central city districts mainly from the Justice Chancellery (now in RGADA, f. 285) was examined and published [3; 5]. Larissa Broitman and Elena Krasnova in their publications on the history of Petersburg streets (Bolshaia Morskaya etc.) touched upon the aspects of household possession in the $18^{\text {th }}-20^{\text {th }}$ centuries [2]. Despite the large number of publications on the architecture of the corresponding period (we mention here only a few $[1 ; 3 ; 5 ; 6 ; 7]$ ) the process of mass residential building up in Russia in the Petrine time has not yet been the subject of precise study.

In this connection the recently published in Russian voluminous (1000 pages) book by the Moscow archivist and historian Mariia V. Nikolaeva Sankt-Peterburg of Peter I: The History of Household Possession - Site Development, Owners and Builders (Sankt-Peterburg Petra I. Istoriia dvorovladenii: zastroika i zastroishhiki) [4] is highly relevant. Nikolaeva focuses on the 
stone and wooden building under orders of gentry in the Petersburg centre in the first third of the $18^{\text {th }}$ century.

It is a successful combination of scientific research and publication of archival documents (from the RGADA funds) clearly seen in the book structure. Comprehensive introductory part, in addition to the "Foreword", includes chapters "The Sources Survey", "The Archeographic Entry" and "An Essay on the History of Private Construction in St. Petersburg of Petrine time".

The first part of the monograph contains a detailed analysis of house possession on the Vasilieskii isle and along the Neva embankments of Admiralteiskii and Gorodskoi islands and Moskovskaia district.

In the second part Nikolaeva lists the contract registers and cites their text.

A lot of black-and-white reproductions of plans and drawings of the first half of the 18th century account for an essential part of the research.

The vast application comprises a glossary, an index, a list of abbreviations. The relevance of the book lies not only in introducing into the scientific use and a deeply serious and compelling analysis of new documents on the history of the Petrine Petersburg architecture, but also, first and foremost, in fixing the household possession topics in modern Russian historiography and developing methods of their comprehensive study.

\section{Литература}

1. Агеева О. Г. «Величайший и славнейший более всех градов в свете...» - град Святого Петра. - СПб.: Русско-Балтийский информационный центр БЛИЦ, 1999. - 344 с.

2. Краснова Е. И. Источники для изучения домовладения Санкт-Петербурга // Петербургские чтения-96. СПб.: Русско-Балтийский информационный центр БЛИЦ, 1996. - С. 212-216.

3. Малиновский К. В. Санкт-Петербург XVIII века. - СПб.: Крига, 2008. - 576 с.

4. Николаева М. В. Санкт-Петербург Петра І. История дворовладений: застройка и застройщики. - М.: Прогресс-Традиция, 2014. - 1008 с.

5. Петров А. Н. Петербургский жилой дом 30-40-х годов XVIII столетия // Ежегодник Института истории искусств. 1960. - М., 1961. - С. 132-157.

6. Семенцов С. В., Красникова О. А., Мазур Т. П., Шрадер Т. А. Санкт-Петербург на картах и планах первой половины XVIII века. - СПб.: Эклектика, 2004. - 436 с.

7. Станюкович-Денисова Е. Ю. Образцовые проекты в жилом строительстве Петербурга 1730-1760-х гг.: проблема типологии и модификации // Актуальные проблемы теории и истории искусства: сб. науч. статей. Вып. 1. / Под ред. С. В. Мальцевой, Е. Ю. Станюкович-Денисовой. - СПб.: НП-Принт, 2011. - С. 174-179.

Title. Sankt-Peterburg of Peter I: The History of Household Possession - Site Development, Owners and Builders by Mariia V. Nikolaeva. Moscow: Progress-Traditsiia Publ., 2014.

Author. Staniukovich-Denisova, Ekaterina Iur'evna — head lecturer. Saint Petersburg State University, Universitetskaia nab., 7/9, 199034 St. Petersburg, Russian Federation. e.stanyukovich-denisova@spbu.ru

Abstract. The article is a brief presentation of the voluminous book by the Moscow archivist and historian of architecture Mariia V. Nikolaeva Sankt-Peterburg of Peter I: The History of Household Possession — Site Development, Owners and Builders, released in Russian by the Progress-Tradition Publ. in 2014. It is a successful combination of scientific research and publication of archival documents (from the RGADA funds) clearly seen in the book structure. Comprehensive introductory part, in addition to the "Foreword", includes chapters "The Sources Survey", "The Archeographic Entry" and "An Essay on the History of Private Construction in St. Petersburg of Petrine time".

The first part of the monograph contains a detailed analysis of house possession on the Vasilieskii isle and along the Neva embankments of Admiralteiskii and Gorodskoi islands and Moskovskaia district. In the second part Nikolaeva lists the contract registers and cites their text. A lot of black-and-white reproductions of plans and drawings of the first half of the 18th century is an essential part of the research. The vast application comprises a glossary, an index, a list of abbreviations. The relevance of the book lies not only in introducing into the scientific use and a deeply serious and compelling analysis of new documents on the history of the Petrine Petersburg architecture, but also, first and foremost, in fixing the household possession topics in modern Russian historiography and developing methods of its comprehensive studies. 
Keywords: St. Petersburg architecture; Petrine time; common residential construction;; Mariia Valentinovna Nikolaeva; history of household possession.

Название статьи. Книга М. В. Николаевой «Санкт-Петербург Петра I. История дворовладений: застройка и застройщики». Москва: Прогресс-Традиция, 2014.

Сведения об авторе. Станюкович-Денисова Екатерина Юрьевна - старший преподаватель. Санкт-Петербургский государственный университет, Университетская наб., 7/9, Санкт-Петербург, Российская Федерация, 199034. e.stanyukovich-denisova@spbu.ru

Аннотация. Статья представляет собой рецензию на объемную книгу московского архивиста и историка архитектуры М. В. Николаевой «Санкт-Петербург Петра І. История дворовладений: застройка и застройщики», выпущенную в 2014 г. издательством «Прогресс-Традиция». Издание являет удачное сочетание научного исследования и публикации архивных документов (из фондов РГАДА), что четко прослеживается в структуре книги. Обширная вводная часть, помимо «Введения» включает в себя главы «Характеристика источников», «Археографическое вступление» и «Очерк истории частного строительства в Санкт-Петербурге петровского времени». Две основные части монографии содержат подробный фундированный анализ дворовладения по набережным Большой и Малой Невы и в линиях Васильевского острова, а также по набережным Большой Невы Адмиралтейской, Московской сторон и Петербургского острова (часть I) и опись и тексты подрядных (часть II). Значительное место занимают приложения в виде терминологического словаря, именного указателя, списка сокращений, а также черно-белые воспроизведения планов и чертежей первой половины XVIII в. Значимость вышедшей книги заключается не только во введении в научный оборот и анализе новых документов по истории петербургской архитектуры петровского времени, но и, в первую очередь, в обращении и разработке на современном этапе темы истории дворовладений в целом и методики ее комплексного изучения.

Ключевые слова: архитектура Петербурга; петровское время; жилая обывательская застройка; Мария Валентиновна Николаева; история дворовладений.

\section{References}

Ageeva O. G. "The great and glorious over all the cities in the world ..." - City of St. Peter. Saint Petersburg, Russian-Baltic Information Center BLITZ Publ., 1999. 344 p. (in Russian).

Krasnova E. I. The Sources for Studying Household Possession in St. Petersburg. St. Petersburg readings 96. Saint Petersburg, Russian-Baltic Information Center BLITZ Publ., 1996, p. 212-216 (in Russian).

Malinovskii K. V. St. Petersburg of the $18^{\text {th }}$ Century. Saint Petersburg, Kriga Publ., 2008. 576 p.

Nikolaeva M. V. Sankt-Peterburg of Peter I: The History of Household Possession - Site Development, Owners and Builders. Moscow, Progress-Traditsiia Publ., 2014. 1000 p. (in Russian).

Petrov A. N. Petersburg Houses in the 30-40s of the 18th Century. Yearbook of the Institute of History of Art. 1960. Moscow, 1961, pp. 132-157 (in Russian).

Sementsov S. V.; Krasnikova O. A.; Mazur T. P.; Schrader T. A. St. Petersburg in the Maps and Plans of the First Half of the $18^{\text {th }}$ Century. Saint Petersburg, Eklektika Publ., 2004. 436 p. (in Russian).

Stanyukovich-Denisova E. Y. Exemplary Projects in House Building of the 1730s-1760s St. Petersburg: Problem of Typology and Modifications. Actual Problems of Theory and History of Art: Collection of articles. Saint Petersburg, Profession Publ., 2011, Vol. 1, pp. 174-179 (in Russian). 